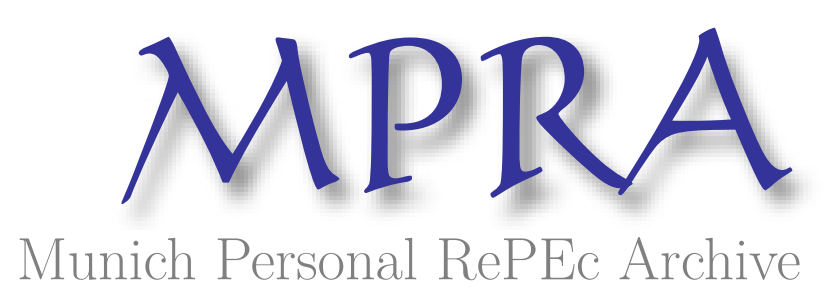

\title{
MAPPING STRATEGIES TO MANAGE FOREST RESOURCES IN INDIA
}

Shah, Deepak

Gokhale Institute of Politics and Economics

9 July 2007

Online at https://mpra.ub.uni-muenchen.de/3920/

MPRA Paper No. 3920, posted 09 Jul 2007 UTC 


\section{MAPPING STRATEGIES TO MANAGE FOREST RESOURCES IN INDIA}

\section{Deepak Shah*}

\section{Introduction :}

Forests occupy a pre-eminent position in our country's economy since they not only influence the agricultural and industrial development but also help in soil and water conservation. In broader terms, Indian forests as elsewhere provide two major functions, one for protective purposes and other for production of products and services. Infact, it was during the second and third five-year plans when due to frequent natural hazards like floods and draughts, our agricultural surplus fell short of the target that the importance of forests management and land use in the country's economy was realized (Chowdhury and Basu, 1967). Thereafter, in every successive five-year plans a considerable emphasis was placed on their consolidation, improvement of degraded forests, establishment of economic plantation of fast growing trees and improvement of communication. The schemes undertaken by the Government during these plans mainly related to forest conservation and protection, forest research, forest education and preservation of wild life. Modern systems of intensive forest management were also adopted. However, the mounting burden of growing population had not only led to widespread shift of forest land for agricultural cultivation but also over exploitation of forest resources (Das, 1983; Marothia, 1989; Singh and Singh 2000). Although various forest laws were enacted from time to time to curb reckless felling of trees, forest related offences such as encroachment of forest land are still seen.

Infact, Indian forests account for a number of products such as timber, firewood, bamboo, gum, resin, tanning material, medicinal herbs, grass, bidi leaves, etc. and provide an important base for industrial development and employment. In 1950s and 1960s many research workers found firewood as highly ubiquitous fuel for the Indian economy (Redman and Chandras, 1967; Dhawan and Satyanarayan, 1967). However, in due course of time, the importance of firewood gradually

\footnotetext{
* Faculty Member, Gokhale Institute of Politics and Economics (Deemed to be a University), Pune 411004 (Maharashtra)

The author is indebted to the anonymous referee of the Journal for his helpful valuable suggestions and critical comments.
} 
declined, especially when other substitutes for energy needs, like LPG, of the rural and urban households were found out. The scenario of late has completely changed and now efforts are made to maintain a proper balance between the conflicting interests of ecological balance and production of forestry products.

Many states in the country have taken various measures to protect their forest resources. And, as a result of this, not only the over exploitation of forest resources has declined considerably but the area under forests as a proportion of total geographical area in the country has also increased from 21 per cent during 1960-61 to 22.80 per cent in $1976-77$ and further to 23.28 per cent in 1996-97. Nonetheless, it is to be noted that in the state of Maharashtra the area under forest as a proportion of total geographical area has declined from a little over 22 per cent during 1960-61 to 20.19 per cent during $1970-71$, though it had marginally increased to 20.87 per cent during 1980-81. During 1996-97, the area under forest as percentage of total geographical area of the state was estimated at 20.76 per cent. Further, the state of Maharashtra is also known to have shown considerable decline in its revenue receipts from state forestry, especially in more recent times. These facts have prompted us to have an insight into the management of forest resources in the state of Maharashtra, especially during the past decade and a half.

\section{Data Base and Methodology :}

Data used for this study were collected from various secondary sources. Time series data for fifteen years (1980-1994) on forest related parameters were collected from various issues of the annual publications of the Forest Department of Maharashtra, 'Annual Report on Administration, Silvicultural Research and Economic Research', Nagpur, and also from 'Handbook of Basic Statistics of Maharashtra State', Directorate of Economics and Statistics, Government of Maharashtra, Mumbai, and 'Statistical Abstract of India', Central Statistical Organisation, Department of Statistics and Programme Implementation, Government of India, New Delhi.

In this study, exponential trend equations have been fitted to the time series data obtained for various parameters from various sources in order to compute compound rates of growth that were also tested for their significance by the student 't' statistics'. Further, with a view to understand growth performance of various 
parameters better and in order to capture year to year fluctuation in the same, an index of instability as suggested by Coppock and subsequently used by Mitra and Shah (1998) was also incorporated in the analysis, which appeared to have taken care of the trend component in the time series data. ${ }^{2}$

An attempt has also been made in this study to estimate the effect of various factors on changes in forest revenue for the state of Maharashtra. The following model has been considered for this purpose:

$$
\text { REV. = f (TFA, LFA, CWFA, EFA) }
$$

where, REV. = revenue receipts per square kilometre of forest area (in Rs.)

$\mathrm{TFA}=$ total forest area in square kilometre

LFA = labour employed (mandays) per square kilometre of forest area

$\mathrm{CWFA}=$ total coupes worked per '000' square kilometre of forest area

EFA $=$ expenditure incurred in harvesting of forest produce per square kilometre of forest area (in Rs.)

The study is divided into three sections. The first section provides an insight into the changing structure in various forest related indicators of Maharashtra. The second section evaluates the distribution of forest area in Maharashtra, the outturn of various major and minor forest produce and income and expenditure pattern on state forestry. It also evaluates some other aspects like working of forest labourer's co-operative societies, extent of social forestry, afforestation, etc. The third section examines the implications of the functional analysis along with inferences and policy implications of the study.

\section{SECTION I}

\section{Forest Related Indicators of Maharashtra :}

Maharashtra accounts for about 7.30 per cent of the total forest area of India. The share of Maharashtra in country's total waste land stands at around 12.30 per cent (Government of India, 1998). The land utilization figures for Maharashtra during the period between 1980/81-1982/83 and 1994/95-1996/97 reveal a marginal decline in barren and uncultivated land and an increase in land put to nonagricultural uses $^{\mathbf{3}}$. Permanent pastures and other grazing lands have also declined sharply during the given period of time. On the other hand, the current and other fallow lands have increased over time (Appendix I). While decline in barren and 
uncultivable land may be considered as desirable for the state's forest economy, the increases in land put to non-agricultural uses, current and other fallow land and at the same time decline in permanent pastures and other grazing land are certainly disturbing phenomena. An attempt, therefore, has been made in this section to provide an insight into the growth and instabilities in various forest related indicators of Maharashtra over the period between 1980/81 and 1993/94. The estimates are brought out in Table 1.

A critical evaluation of Table 1 revealed a sharp decline in forest revenue as a percentage of state's total revenue during the given period of time. The major cause of this decline was traced in the slower growth in forest revenue as compared to the total revenue for the state. Between 1980/81 and 1993/94, while total state revenue grew at the rate of 15 per cent a year, the growth in forest revenue was only 6 per cent a year. The slower growth in forest revenue in turn was mainly due to very slow growth in the total value of forest produce harvested, especially after the late eighties period. It is to be noted that during the late eighties the Government had banned felling of trees in many parts of the state. ${ }^{4}$ This has not only affected forest area harvested but also value of forest produce harvested (Table 1). Further, in due course of time there has been considerable increase in outstanding forest revenue. There are multiple reasons for the same, which are cited in Appendix 2. The major causes of decline in outstanding forest revenue were traced in the sharp increases in amount of outstanding forest revenue due from forest contractors, non-receipt of dues from Forest Labourer's Co-operative Society (F.L.C.S.) and non-receipt of challans from treasury.

The ban on felling of trees has also led to sharp decline in total number of coupes worked in forest area, which has drastically fallen from 825 during the triennium ending 1982/83 to as low as 126 during the triennium ending 1993/94. Similarly, labour employment has also been affected, especially after the late eighties period. On the positive side, there has been decline in number of forest offences. The area under various plantation activities has increased considerably over time. Afforested area has grown over 10 per cent a year between 1980/81 and 1993/94. However, the disquieting features have been increase in number and size of fire and sharp decline in forest area harvested by Forest Labourer's Co-operative 
Society (FLCS). The area harvested by FLCS has been declining at the rate of about 3 per cent a year during the given part of time. The expenditure on forest related activities has increased tremendously with the growth rate of about 15 per cent a year during the given period of time. Further, the index of instability also reveal considerable year to year fluctuation in the rates of growth of total forest area harvested, area harvested by FLCS, expenditure incurred on forestry related activities, number of coupes worked in forest area, value of forest produce harvested, and labour employed in forest area.

Thus, the foregoing evaluation reveals either a decline or very slow growth in most of the forest related indicators of Maharashtra. Although the State Government has initiated various measures to conserve its forest resources, these have also affected harvesting of forest produce and in turn state revenue from forestry. ${ }^{5}$ However, a significant increase in afforested area in the state is certainly a welcome development.

\section{SECTION II}

\section{Distribution of Forest Area in Maharashtra :}

In the state of Maharashtra, while reserved forest account for 64 per cent of the total forest area, the shares of protected and unclassed forest are about 24 per cent and 9 per cent, respectively. The forest area in the state is distributed among 11 forest circles and 7 wild life divisions. ${ }^{6}$ Information regarding growth and instabilities in the distribution of forest area among various controlling agencies are provided in Table 2. An evaluation of Table 2 clearly shows a marginal decline in forest area cover under the purview of forest and revenue departments during the period between 1980/81 and 1993/94. Although Table 2 also shows a marginal increase in total forest area cover in the state, this increase in forest area has been due mainly to a sharp increase in area transferred to Forest Development Corporation of Maharashtra (FDCM) during the given period of time. This is also evident from instability index, which show a very high fluctuation in rate of growth in area transferred to FDCM. 


\section{Outturn of Major and Minor Forest Produce in Maharashtra :}

The trends regarding outturn of major and minor forest produce show interesting results which are provided in Table 3. Between 1980/81 and 1993/94, the outturn of major forest produce declined considerably in the state of Maharashtra. Infact, timber and firewood are by far the two major forest produce which have shown a declining trend in their outturn in quantity as well as in value terms, especially after the late eighties period. The decline in outturn of firewood has been more sharp as compared to timber, especially after the late eighties period when a ban on felling of trees in certain parts of the state was imposed. Further, the decline in outturn of forest produce harvested by Forest Labourer's Co-operative Society (FLCS) has been more sharp as compared to the produce harvested by Forest Department (FD) and right and privilege holders. The index of instability also reveal very wide fluctuation in rates of decline in major forest produce harvested by FLCS as compared to produce harvested by other agencies, both in quantity and value terms.

The most interesting feature emerging out from Table 3 is the sharp increase in outturn of minor forest produce. The reason for the increase in outturn of minor forest produce could be not only due to increase in volume and prices but also due to certain policy changes in favour of harvesting of minor forest produce. It is to be noted that of late government policies discourage harvesting of major forest produce and at the same time encourage harvesting of minor forest produce. This is also evident from the fact that during the given period of time there has been sharp increase in outturn of minor forest produce in the face of very slow growth in outturn of major forest produce ( Table 3 ). Thus, decline in outturn of major forest produce, especially during the period between late eighties and early nineties, has been more than compensated by an increase in the outturn of minor forest produce. ${ }^{7}$ Further, the major reason for the sharp rise in total outturn of minor forest produce could be traced in the steep rise in outturn of tendu leaves (bidi leaves), especially after the late eighties period. This is mainly due to certain policy changes with regard to sale of tendu leaves. The other minor forest produce which have shown considerable rates of growth over time are bamboo, gum and moha. In general, while outturn of 
major forest produce has grown by less than 2 per cent a year during the period between 1980/81 and 1993/94, the growth in outturn of minor forest produce turns out to be as high as nearly 20 per cent a year during the same period.

There could be several implications for the increasing trend in outturn of minor forest produce. One of the major implications could be that the exploitation of these produce had increased, especially when there was a ban on harvesting of major forest produce. It is to be noted that of late forest conservation and bio-diversity issues have acquired newer dimensions. Therefore, management of minor forest produce as a viable alternative to major forest produce has begun to attract attention. More importantly, a realization has already emerged to shift focus on high value minor forest produce like tendu leaves, bambo, etc., whose harvesting could meet the objective of revenue generation for the forestry sector without affecting forest conservation measures.

\section{Compositional Changes in Forest Revenue and Expenditure in Maharashtra :}

The trends in forest revenue and total expenditure on forest related activities show statistically significant increases (Table1). However, such trends do not reveal the sources that have contributed to this increase in forest revenue or the activities that have led to the increase in forest expenditure. In this section an attempt is made to evaluate the compositional changes in forest revenue and expenditure in Maharashtra during the period between 1980/81 and 1993/94. The results are brought out in Table 4.

It is to be noted that while timber accounted for the maximum share in total net forest revenue of the state during the early-and the late eighties period, the scenario was completely changed during the early nineties when the major contributors to the net forest revenue of the state were bidi leaves (tendu leaves), timber and bamboo. The share of revenue receipts from the sale of timber and firewood was found to decline at the rate of 1.39 per cent and 8.50 per cent a year during the period between 1980/81 and 1993/94. On the other hand, the increase in share of revenue receipts from the sale of bidi leaves was as high as newly 10 per cent a year during the same period. Another interesting feature was the marked decline in share of receipts from FDCM in total net forest revenue of the state; the decline being to the tune of about 24 per cent a year during the given period of time. 
It deserves mention here that the main source of revenue receipts of the FDCM was from harvesting of major forest produce from the Western Ghat Region. ${ }^{\mathbf{8}}$ The ban on felling of trees in this region, therefore, largely affected the business of FDCM. As a result, revenue receipts from FDCM declined sharply during the given period of time.

As for expenditure, the major forest expenditure activities turned out to be administration and forest protection, harvesting of forest produce, natural and artificial regeneration and plantation, FDCM loans and payments, and expenses on various programmes such as DPAP, Western Ghat Development, etc. During the given period of time, there was considerable increase in expenditure on forest protection and administration, afforestation and soil conservation, wild life management and natural and artificial regeneration and plantation. However, the expenditure on harvesting of forest produce was found to decline sharply so much so that there was about 4 per cent decline in share of this activity in total forest expenses during the given period of time.

The possible reason for the rise in expenditure on certain forest related activities like forest protection, afforestation, soil conservation, wild life management and nature conservation, etc. could be due to changes in government policies in favour of these activities. In fact, the increase in expenditure on these forest related activities was noticed only after the late eighties period when the government had not only banned felling of trees in certain parts of the state but also encouraged the above activities with a view to maintain ecological balance in the state. As a result of this, there has been continuous increase in expenditure on the aforementioned forest related activities since the late eighties.

Thus, the exorbitant cost of protection and preservation of forest resources could be considered as a matter of concern, especially when there is deficit in revenue receipts from state forests, particularly during the more recent times.

\section{Afforestation Under Various Activities :}

Afforested area in the sate of Maharashtra has increased considerably during the past decade and a half ${ }^{9}$ (Appendix 3). Afforestation is carried out under plan scheme and also under various development programme. Under plan scheme, 
plantation of teak, bamboo, and mixed species are undertaken. It is to be noted that major afforestation in the state is carried out under employment guarantee scheme, followed by plan scheme and also under Western Ghat Development Programme.

\section{Working of FLCS :}

The ban on felling of trees in the state has clearly affected the working of FLCS ${ }^{10}$. Although numerical strength of FLCS has increased during the period between 1980/81 and 1993/94, the period gone by has also been marked with sharp decline in number of coupes worked, area harvested by FLCS and total realization from harvesting of produce (Appendix 4). There is considerable labour displacement because of decline in harvesting of produce. However, this labour is seen to have been provided employment under various other schemes such as Employment Guarantee scheme which undertakes plantation, afforestation, soil conservation, construction and improvement of road, etc.

\section{Employment Opportunities in Forestry Operations :}

Forests provide considerable employment opportunities to a large section of adivasi and backward class population residing in forest tracts. An attempt, therefore, has been made to evaluate the extent of human labour absorption during various forest related operations, especially during the period between early eighties and the early nineties. These estimates are brought out in Table 5.

A critical evaluation of Table 5 revealed a sharp increase in total human lobour absorption in forestry operations during the period between early- and the late eighties with a marginal decline in the same after the late eighties period. However, the period gone by was seen to be marked with some major changes, especially in terms of extent of human labour absorption during various operations. In due course of time while labour employment in exploitation of forest produce declined sharply, a steady increase in extent of human labour absorption was also noticed in improvement, organization and extension activity. In fact, improvement, organization and extension is a group of activities that include direction and forest administration, nature conservation, forest development, plantation, afforestation, and also forest labour welfare. The reason for decline in labour force engaged in harvesting of forest produce was mainly due to ban on felling of trees which came 
into effect during the late eighties. As pointed out earlier, this displaced labour was provided employment not only in various other forest related activities but also under Employment Guarantee Scheme ( EGS ). As a result, labour absorption under EGS scheme rose sharply during the given period of time. However, the point that merits attention is that despite sharp decline in labour employment in harvesting of forest produce, total labour absorption in various forest related operations kept increasing in course of time. This clearly shows the extent to which employment opportunities in forest related operations are generated and sustained in the state of Maharashtra.

\section{Social Forestry in Maharashtra :}

In broader terms, social forestry implies growing trees on private, community, or government non-forest land primarily for meeting the local community's basic needs of fuel wood, small wood, and fodder and for providing a supplementary source of income to tree growers and the rural poor ( Singh, 2000 ). In the state of Maharashtra, the main objectives of social forestry are : (i) to cater to the needs of rural poor, especially in terms of their needs of fuel wood, small timber, grass, fruits etc., and thus reduce pressure on forest land, (ii) to reduce the rate of deforestation, and (iii) to increase rural employment. In order to achieve these objectives, various schemes have been implemented that mainly include: (a) plantation of trees on the private lands belonging to SC/ST (marginal farmers), (b) block plantation, (c) Western Ghat Development Programme, (d) Smruti Udyan, (e) Kisan Ropwatika Yojana, (f) Vanamahotsava (Non-Plan), (i) Central Nursery (Nonplan), (h) Water Conservation Programme, (i) Drought Prone Area Programme, (f) Employment Guarantee Scheme, and (k) Jawahar Rojgar Yojana.

Most of the above programmes are still in their implementation phase in Maharashtra. Therefore, at this stage it may not be possible to evaluate the contribution of these programmes towards management of forest resources. However, there are numerous studies that have dealt with the impact evaluation of government managed social forestry projects ( e.g., SIDA, 1987; Behal, 1990; CIDE, 1990; USAID, 1990; Venkateswaran, 1995 ). All these studies have come out with some general conclusions regarding social forestry in India. Among various 
components of social forestry, farm forestry has been cited as the most popular with big farmers emerging as the main beneficiaries of such forestry. Creation of employment opportunities has also been cited as one of the other positive feature of social forestry. Nevertheless, these studies have also found that the approach of social forestry is more physical target - oriented with very little emphasis on community participation and sociological aspects.

\section{SECTION III}

\section{Determinants of Forest Revenue :}

In order to estimate the effect of factors on total forest revenue of Maharashtra, regressions are estimated. The time series data covering the period $1980 / 81$ to $1993 / 94$ are being used in the estimation. Three alternative specifications (Linear, Semi-log and Cobb-Douglas) are estimated. However, the results of only linear specification of the equation are reported considering $\mathrm{R}^{2}, \mathrm{D}-\mathrm{W}$ and statistical significance of variables, which, in this specification, turned out to be better.

$$
\begin{aligned}
& \text { REV } .=-32765.78+0.4681 \mathrm{TFA}+13.4614^{*} \mathrm{LFA}+358.7421^{* *} \mathrm{CWFA}+3.5665^{* * *} \mathrm{EFA} \\
& \text { Adjusted } R^{2}=0.7497 \quad \text { F-Statistics }=9.9853 \quad \text { Durbin-Watson }=1.7183
\end{aligned}
$$

Figures in parentheses show the standard errors of regression coefficients. $* * *, * *$ and $*$ indicate significance of regression coefficients at one, five and ten per cent level of probability, respectively.

The independent variables explained 75 per cent variation in forest revenue. Except area under forest, all the variables are statistically significant and D-W show no first order auto correlation of the errors. The results indicate that higher use of labour, number of coupes worked and expenditure on harvesting of produce will lead to increase in total forest revenue of Maharashtra. Because of very slow growth in forest area, the response coefficient of this factor is noticed to be insignificant.

\section{Policy Implications :}

In order to maintain ecological balance and conserve its forest resources, the Government of Maharashtra has initiated various measures and programmes. Although the measures adopted in more recent times have resulted in an increase in 
afforested area as well increase in plantations under various crops, these measures have also some adverse effects, especially in terms of harvesting of produce and thereby net returns from state forestry. The decline in revenue receipts from forests coupled with sharp increase in expenditure on forestry related activities, especially on administration and forest protection, have certainly affected the forest economy of the state. The ban on felling of trees and increase in afforested area in the state could certainly be considered as welcome developments. However, a more appropriate strategy could have been to adopt such policy measures that not only prevent felling of trees in certain parts of the state but also help in intensifying afforestation in some other identified parts of the state and, at the same time, allowing harvesting /deforestation of high yielding varieties of major and minor forest produce in certain specific pockets of the state. The balance in the some could not only have helped the state to increase its revenue receipts from state forestry but also in respect of achieving its goal of maintaining ecological balance in the state.

Of late, afforestation of the waste and unproductive lands has acquired new dimension and importance (Yadav, 1980; Chaturvedi, 1985). Unfortunately, the waste and other fallow land in the state are increasing over time. Earlier, afforestation on waste lands of village panchayats was stressed by Joshi and Agnihotri (1983). Efforts, therefore, should be made to bring these lands under forest cover of the state. In brief, a more realistic and egalitarian approach should be adopted by the Government that should not only include forest conservation but also meeting the increasing demands of forest resources. In order to achieve this objective, such policy initiatives should be adopted that mainly aim at maintaining protective forests for the preservation of soil erosion, floods, land slips, controlling water supply and retaining sub-soil water, and preserving wild life for scenic beauty and recreation; maintaining a minimum area of high forests to supply commercial timber for constructional purposes, maintaining wood lands for the supply of much needed fuel wood; and reorganizing forests with the deliberate objective of establishing and developing a number of highly profitable industries (Mamoria, 1967). 


\section{End Notes}

1. The equation fitted to analyse the trend is semi-log exponential form

$$
\begin{array}{ll}
\mathrm{y} & =\mathrm{e}^{\mathrm{A}+\mathrm{Bt}} \\
\log \mathrm{y} & =\mathrm{A}+\mathrm{B} * \mathrm{t}
\end{array}
$$

The compound growth rates $(r)=\left(e^{\mathrm{B}}-1\right) \times 100$ were tested for their significance by the student ' $t$ ' statistics.

2. According to Coppock, the annual instability index equals the anti-log of the square root of the logarithmic variance. The series is given in algebraic form as

$$
\begin{aligned}
& \mathrm{V} \log =\frac{1}{\mathrm{~N}-1} \sum\left[\log \mathrm{X}_{\mathrm{t}+1}-\log \mathrm{X}_{\mathrm{t}}-\frac{1}{\mathrm{~N}-1} \quad \sum\left(\log \mathrm{X}_{\mathrm{t}+1}-\log \mathrm{X}_{\mathrm{t}}\right)\right]^{2} \\
& \text { or } \\
& {\left[\log \frac{X_{t+1}}{X_{t}}-m\right]^{2}} \\
& \mathrm{~V} \log = \\
& \mathrm{N}-1
\end{aligned}
$$

Where, $\mathrm{N}=$ Number of years $; \mathrm{X}=$ Value of the parameter $\mathrm{m}=$ Mean value of the logarithmic first difference

3. The barren and uncultivated land in the state was estimated to be 1728 thousand hectares during triennium ending 1982/83 and 1713 thousand hectares during triennium ending 1996/97. Land put to non-agricultural uses was estimated to be 994 thousand hectares during triennium ending 1982/83 and 1238 thousand hectares during triennium ending 1996/97. The estimated figures for the permanent pastures and other grazing land were 1586 thousand hectares during triennium ending 1982/83 and 1358 thousand hectares during triennium ending 1996/97. The current and other fallow lands in the state were estimated to be 858 thousand hectares and 802 thousand hectares during triennium ending 1982/83 and 1036 thousand hectares and 1106 thousand hectares during triennium ending 1996/97.

4. As per Government directives issued on dated 07.06.1988 there was a ban on felling of trees (i) from certain area like Western Ghat Region, etc. (ii) the forest area with less than 0.4 density, and (iii) in the forest area for which the period of working plan is over.

5. While during the early- and the late eighties the revenue receipts from state forestry was more than expenditure, the scenario was seen to reverse during the early nineties when expenditure on forestry exceeded revenue receipts from state forestry. 
6. The total territorial circle include 11 forest circles in Maharashtra namely, Thane, Nasik, Dhule, Pune, Kolhapur, Aurangabad, Amravati, Yavatmal, Nagpur, North Chandrapur and South Chandrapur. Among these circles, North and South Chandrapur, Nagpur and Yavatmal put together account for more than 50 per cent of the total forest area of the state. Various Wild Life Divisions (WLD) of the state include Thane WLD, Pune WLD, Nagpur WLD, Chandrapur WLD, Borivali National Part, Project Tiger, Paratwade, and Tadoba National Park, Chandrapur.

7. While during the early eighties, the shares of major and minor forest produce in total outturn of forest produce harvested were 81.44 per cent and 18.56 per cent, respectively, the scenario was seen to change during the early nineties when contribution of minor forest produce alone was 54.71 per cent to the total outturn of forest produce harvested.

8. The FDCM Limited is a company which came into being on 16 Feb., 1974 under the Indian Companies Act. All the shares of this company are owned by the Government of Maharashtra. The major objective of the FDCM is to undertake various activities like plantations of economically important species like teak, bamboo, khair semal and such other suitable species, export, import, processing and distribution of forest produce, trees, crops, natural products and agricultural and silvicultural cash crops, and also to carry out business as manufacturers of and dealers in plywood, pulpwood, matchwood, wood blocks for flooring and other activities like manufacture of boxes, windows, doors, furniture and articles of all description wholly or partly made from wood or forest produce, etc.

9. The afforested area in the state of Maharashtra has increased from 25.44 thousand hectares during the early eighties to 67.47 thousand hectares in the early nineties. The afforestation carried out under employment guarantee scheme was found to be as high as 60-70 per cent of the total afforested area in the state.

10. Harvesting of major and minor forest produce is undertaken through agencies such as Forest Department and purchasers which include private contractors and FLCS. The agency of forest contractors has been stopped from exploiting the forest area ever since 1981/82.

\section{References :}

Behal, Monisha (1990), 'Social Forestry in Bihar with Special Reference to NGOs 
and Involvement of Women in the Project Area', Indo-Swedish Forestry Co-ordination Programme, Swedish International Development Agency (SIDA) and Swedforest, New Delhi.

Canadian International Development Agency (CIDA) (1990), 'Women in Forestry:A Case Study of the Andhra Pradesh Social Forestry Project', India.

Chowdhury, T.K. and S.K. Basu (1967), 'Role of Forestry Development in Indian Economy', Indian Journal of Agricultural Economics, Vol. 12, No. 4, October - December, pp. 183-188.

Chaturvedi, A.N. (1985), 'Waste Land Afforestation', The Indian Forester, Vol. 111, No. 11, pp. $919-926$.

Dhawan, B.D. and Y. Satyanarayana (1967), 'The Role of Firewood in the Indian Economy', Indian Journal of Agricultural Economics, Vol. 12, No. 4, October - December, pp. 169-173..

Das, H.C.L. (1983), 'A Study of Regional Distribution and Trends in Area, Production and Yield of Forests in Bihar', Indian Journal of Agricultural Economics, Vol. 38, No. 3, July-September, pp. 285-291.

Government of India (1998), 'Statistical Abstract of India', Central Statistical Organisation, Department of Statistics and Programme Implementation, Government of India, New Delhi.

Joshi, P.K. and A.K. Agnihotri (1983), 'Ex Ante Assessment of Afforestation for Fuelwood on Waste Lands - A Multi - Objective Programming Approach', Indian Journal of Agricultural Economics, Vol. 38, No. 3, July - September, pp. 308-316.

Mamoria, C. B. (1967), 'National Forest Policy and Forestry Development in India', Indian Journal of Agricultural Economics, Vol. 12, No. 4, OctoberDecember, pp. 173-177.

Marothia, Dinesh K. (1989), 'Socio-Economic Rationales of Waste Land Afforestation', Journal of Tropical Forestry, Vol. 5, No. 4, pp. 343-350.

Mitra, Ashok K., and Deepak Shah (1998), 'Agricultural Export Potential of India in the Changing Economic Environment', in 'Changing Prospectives in Indian Agriculture', S. G. Bhanushali and A.G. Pujari (ed.) published by Professor R. R. Doshi Felicitation Committee, Kolhapur University, Kolhapur.

Redman, C. John and G. S. Chandras (1967), 'Needed Research in Economics of Indian Forestry', Indian Journal of Agricultural Economics, Vol. 12, No. 4, October - December, pp. 152 - 162. 
Singh, Katar (2000), 'An Evaluation of Some Selected Social Forestry Models Adopted in India', Indian Journal of Agricultural economics, Vol 55, No 3, July - September, pp. 423-434.

Singh, R.P. and S.K. Singh (2000), 'Forest and People's Participation (Badri Gram Van Raksha Committee)', Indian Journal of Agricultural Economics, Vol. 55, No. 3, July-September, pp. 443-444.

Swedish International Development Agency (SIDA) (1987), 'Evaluation of the SIDA Supported Social Forestry Project in Orissa', India, New Delhi.

United States Agency for International Development (USAID) (1990), Final Evaluation of Maharashtra Social Forestry Project, New Delhi.

Venkateswaran, Sandhya (1995), 'Environment, Development and Gender Gap, Sage Publications India Pvt. Ltd., New Delhi.

Yadav, J.S.P. (1980), 'Salt Affected Soil and Their Afforestation', The Indian Forester, Vol. 106, No. 4, pp. 19-27.

LESSONS 
Table 1: Changing Structure in Forestry Related Indicators of Maharashtra: 1980-1994

\begin{tabular}{|c|c|c|c|c|c|c|}
\hline Sr. & \multirow[t]{2}{*}{ Particulars } & \multicolumn{3}{|c|}{ Triennium Ending } & \multicolumn{2}{|c|}{ 1980-1994 } \\
\hline No. & & $1982 / 83$ & $1988 / 89$ & $1993 / 94$ & $\operatorname{CGR}(\%)$ & $\mathrm{CII}(\%)$ \\
\hline 1 & Total State Revenue (Rs. Crore) & 2341.67 & 5420.00 & 10422.00 & 15.09 & 5.08 \\
\hline 2 & Revenue from Forest (Rs. Crore) & 67.47 & 126.92 & 113.19 & 6.42 & 16.61 \\
\hline 3 & $\begin{array}{l}\text { Forest Revenue to State Revenue } \\
\text { (per cent) }\end{array}$ & 2.88 & 2.34 & 1.09 & -7.53 & 14.95 \\
\hline 4 & $\begin{array}{l}\text { Total Expenditure on Forest ((Rs. } \\
\text { Crore) }\end{array}$ & 39.60 & 86.64 & 146.88 & 14.67 & 9.47 \\
\hline 5 & Total Forest Area ( Sq. Km.) & 62254 & 62936 & 63874 & $0.20^{\mathrm{NS}}$ & 2.30 \\
\hline 6 & $\begin{array}{l}\text { Forest Area as per cent of total } \\
\text { Geographical Area of State }\end{array}$ & 20.87 & 20.76 & 20.76 & -0.06 & 0.11 \\
\hline 7 & $\begin{array}{l}\text { Revenue Per Sq.Km. of Forest Area } \\
\text { (Rs.) }\end{array}$ & 10814 & 20182 & 17721 & 6.21 & 16.61 \\
\hline 8 & $\begin{array}{l}\text { Expenditure Per Sq.Km. of Forest } \\
\text { Area (Rs.) }\end{array}$ & 6361 & 13766 & 22995 & 9.53 & 31.41 \\
\hline 9 & $\begin{array}{l}\text { Labour Employed in Forestry } \\
\text { Operations ( '000' Mandays) }\end{array}$ & 26877 & 34315 & 33828 & 5.20 & 23.66 \\
\hline 10 & Wages Paid to Labour (Rs. Lakhs) & 1866 & 4119 & 7500 & 17.05 & 20.88 \\
\hline 11 & $\begin{array}{l}\text { Labour Employed Per Sq. Km. of } \\
\text { Forest Area ( Mandays) }\end{array}$ & 432 & 545 & 530 & 5.00 & 24.24 \\
\hline 12 & Total No. of Coupes Worked & 825 & 664 & 126 & -17.16 & 62.84 \\
\hline 13 & $\begin{array}{l}\text { Total Coupes Worked Per '000' Sq. } \\
\text { Km. Of Forest Area }\end{array}$ & 13.20 & 10.60 & 1.97 & -17.33 & 63.76 \\
\hline 14 & $\begin{array}{l}\text { Outstanding Forest Revenue (Rs. } \\
\text { Lakhs) }\end{array}$ & 765.36 & 1683.15 & 1983.81 & 9.57 & 17.70 \\
\hline 15 & $\begin{array}{l}\text { Total Value of Forest Produce } \\
\text { Harvested (Rs. Lakhs ) }\end{array}$ & 5540.60 & 11007.63 & 11138.46 & 7.42 & 13.00 \\
\hline 16 & $\begin{array}{l}\text { Total Forest Area Harvested } \\
(\mathrm{Sq} . \mathrm{Km})\end{array}$ & 786.43 & 510.80 & 149.62 & -17.58 & 50.97 \\
\hline 17 & $\begin{array}{l}\text { Value of Forest Produce Harvested } \\
\text { Per Sq. Km. of Forest Area } \\
\text { Harvested ( Lakh Rs.) }\end{array}$ & 7.02 & 29.52 & 74.44 & 30.34 & 48.06 \\
\hline 18 & $\begin{array}{l}\text { Labour Employed Per Sq. Km. of } \\
\text { Forest Area Harvested ( '000' } \\
\text { Mandays) }\end{array}$ & 34.13 & 94.57 & 226.09 & 27.64 & 69.13 \\
\hline 19 & $\begin{array}{l}\text { Total Coupes Worked Per '000' Sq. } \\
\text { Km. of Forest Area Harvested }\end{array}$ & 1062.54 & 1216.17 & 842.13 & $0.51^{\mathrm{NS}}$ & 45.12 \\
\hline 20 & Number of Forest Offences & 87109 & 82685 & 77636 & $-0.82^{\mathrm{NS}}$ & 7.89 \\
\hline 21 & Number of Fires & 1376 & 1071 & 1318 & $2.03^{\mathrm{NS}}$ & 41.50 \\
\hline 22 & Size of Fire ( Sq. km.) & 214.67 & 304.45 & 648.31 & 8.60 & 34.50 \\
\hline 23 & $\begin{array}{l}\text { Plantation Under Various Activities } \\
\text { ( Ha) }\end{array}$ & 23393 & 26238 & 38036 & $1.76^{\mathrm{NS}}$ & 51.42 \\
\hline 24 & $\begin{array}{l}\text { Afforestation under Various } \\
\text { Activities ( } \mathrm{Ha} \text { ) }\end{array}$ & 28221 & 58225 & 67895 & 10.63 & 35.53 \\
\hline 25 & $\begin{array}{l}\text { Percentage of Forest Area worked } \\
\text { by - Forest Department } \\
\text { - FLCS }\end{array}$ & $\begin{array}{l}57.67 \\
42.33\end{array}$ & $\begin{array}{l}65.92 \\
34.08\end{array}$ & $\begin{array}{l}79.37 \\
20.63\end{array}$ & $\begin{array}{l}0.88^{\mathrm{NS}} \\
-2.67^{\mathrm{NS}}\end{array}$ & $\begin{array}{l}29.64 \\
55.22\end{array}$ \\
\hline 26 & $\begin{array}{l}\text { Area destroyed by Fire As } \\
\text { Percentage of Total Forest Area } \\
\text { Attempted for Fire Protection }\end{array}$ & 0.41 & 0.54 & 1.61 & 8.03 & 34.68 \\
\hline
\end{tabular}

Note : 1) CGR = Compared Growth Rates; CII = Coppock Instability Index

2) All Growth Rates Significant at $1 \%$ Level of Probability

3) NS = Not Significant at $1 \%$ Level of Probability 
Table 2: Distribution of Forest Area in Maharashtra: 1980-1994

(Area in Sq. Km.)

\begin{tabular}{|c|c|c|c|c|c|c|c|}
\hline & \multirow[t]{2}{*}{ Controlling Agency } & \multirow[t]{2}{*}{ Forest Type } & \multicolumn{3}{|c|}{ Triennium Ending } & \multicolumn{2}{|c|}{ 1980-1994 } \\
\hline & & & $1982 / 83$ & $1988 / 89$ & $1993 / 94$ & $\operatorname{CGR}(\%)$ & $\mathrm{CII}(\%)$ \\
\hline \multirow[t]{4}{*}{ A } & Forest Department & Reserved & 38993 & 38968 & 39109 & Neg. & 1.64 \\
\hline & & Protected & 15140 & 15112 & 14845 & -0.15 & 0.29 \\
\hline & & Unclassed & 2445 & 2303 & 2295 & -0.81 & 2.93 \\
\hline & & Total & 56578 & 56383 & 56249 & $-0.07^{\mathrm{NS}}$ & 1.15 \\
\hline \multirow[t]{8}{*}{$\mathrm{B}$} & Revenue Dept. & Reserved & 1551 & 1425 & 1383 & -1.10 & 3.65 \\
\hline & & Protected & 151 & 137 & 135 & -1.22 & 2.33 \\
\hline & & Unclassed & 3511 & 3502 & 3731 & 0.60 & 1.80 \\
\hline & & Total & 5213 & 5064 & 5249 & $0.07^{\mathrm{NS}}$ & 1.60 \\
\hline & Total Area $(\mathrm{A}+\mathrm{B})$ & Reserved & 40544 & 40393 & 40492 & $-0.04^{\mathrm{NS}}$ & 1.59 \\
\hline & & Protected & 15291 & 15249 & 14980 & -0.16 & 0.29 \\
\hline & & Unclassed & 5956 & 5805 & 6026 & $0.04^{\mathrm{NS}}$ & 1.54 \\
\hline & & Total & 61791 & 61447 & 61498 & $-0.06^{\mathrm{NS}}$ & 1.10 \\
\hline \multirow[t]{2}{*}{ C. } & $\begin{array}{l}\text { Area Transferred to } \\
\text { Private Forest Broug } \\
\text { Possession of FD }\end{array}$ & $\begin{array}{l}\text { M Including } \\
\text { ader }\end{array}$ & 463 & 1489 & 2376 & 21.55 & 16.21 \\
\hline & Total Forest Area (A & & 62254 & 62936 & 63874 & $0.20^{\mathrm{NS}}$ & 2.30 \\
\hline
\end{tabular}

Note: As in Table 1. 
Table 3: Outturn of Major and Minor Forest Produce in Maharashtra: 1980-1994

(Quantity in '000' cum. and value in lakh Rs.)

\begin{tabular}{|c|c|c|c|c|c|c|c|}
\hline \multirow{2}{*}{\multicolumn{3}{|c|}{ Forest Produce }} & \multicolumn{3}{|c|}{ Triennium Ending } & \multicolumn{2}{|c|}{ 1980-1994 } \\
\hline & & & $1982 / 83$ & $1988 / 89$ & $1993 / 94$ & $\mathrm{CGR}(\%)$ & $\mathrm{CII}(\%)$ \\
\hline \multirow[t]{21}{*}{$\mathbf{A}$} & Major Forest Produce & & & & & & \\
\hline & (a) Forest Department & & & & & & \\
\hline & (i) Timber & Quantity & 193.22 & 165.55 & 86.44 & $-0.45^{\mathrm{NS}}$ & 22.10 \\
\hline & & Value & 2309.66 & 5890.24 & 4511.85 & 0.81 & 30.44 \\
\hline & (ii) Firewood & Quantity & 490.27 & 345.52 & 143.01 & -0.75 & 31.97 \\
\hline & & Value & 392.13 & 675.02 & 354.82 & $0.16^{\mathrm{NS}}$ & 35.57 \\
\hline & $\begin{array}{l}\text { (b) Forest Labourer's Cooperative } \\
\text { Society }\end{array}$ & & & & & & \\
\hline & (i) Timber & Quantity & 104.23 & 73.50 & 3.73 & $-1.50^{\mathrm{NS}}$ & 49.14 \\
\hline & & Value & 1351.91 & 2525.23 & 111.34 & $-0.37^{\mathrm{NS}}$ & 55.36 \\
\hline & (ii) Firewood & Quantity & 472.31 & 260.70 & 26.97 & $1.60^{\mathrm{NS}}$ & 36.42 \\
\hline & & Value & 408.56 & 369.44 & 50.95 & $0.95^{\mathrm{NS}}$ & 85.82 \\
\hline & $\begin{array}{l}\text { (c) Right and Privilege Holders } \\
\text { and Free Granters }\end{array}$ & & & & & & \\
\hline & (i) Timber & Quantity & 2.80 & 2.50 & 0.01 & $-1.33^{\mathrm{NS}}$ & 199.88 \\
\hline & & Value & 22.90 & 38.09 & 0.08 & $-0.97^{\mathrm{NS}}$ & 179.22 \\
\hline & (ii) Firewood & Quantity & 41.05 & 75.29 & 11.22 & $-0.07^{\mathrm{NS}}$ & 131.10 \\
\hline & & Value & 27.19 & 119.70 & 15.34 & $0.68^{\mathrm{NS}}$ & 138.85 \\
\hline & Total Major Forest Produce & & & & & & \\
\hline & (i) Timber & Quantity & 300.25 & 241.55 & 90.18 & $-0.66^{\mathrm{NS}}$ & 22.29 \\
\hline & & Value & 3684.47 & 8453.57 & 4623.27 & -0.57 & 29.09 \\
\hline & (ii) Firewood & Quantity & 1003.63 & 681.50 & 181.20 & -0.96 & 24.24 \\
\hline & & Value & 327.88 & 1164.17 & 421.11 & $0.14^{\mathrm{NS}}$ & 40.86 \\
\hline \multirow[t]{11}{*}{ B } & Minor Forest Produce (Value) & & & & & & \\
\hline & (i) Bambo & & 259.65 & 443.31 & 1390.64 & 17.06 & 98.81 \\
\hline & (ii) Grass and Grazing & & 46.26 & 96.07 & 63.71 & $2.16^{\mathrm{NS}}$ & 35.17 \\
\hline & (iii) Bidi Leaves & & 631.92 & 726.67 & 4455.04 & 21.83 & 81.84 \\
\hline & (iv) Gum & & 24.58 & 36.38 & 63.00 & 9.99 & 44.73 \\
\hline & (v) Hirda & & 9.03 & 4.71 & 18.27 & $5.22^{\mathrm{NS}}$ & 44.17 \\
\hline & (vi) Moha (Flower) & & 3.96 & 26.01 & 58.09 & 24.53 & 201.02 \\
\hline & (vii) Other MFP & & 52.096 & 56.21 & 45.33 & $0.19^{\mathrm{NS}}$ & 41.06 \\
\hline & $\begin{array}{l}\text { Total Value of Minor Forest } \\
\text { Produce }\end{array}$ & & 1028.26 & 1389.86 & 6094.08 & 18.97 & 61.27 \\
\hline & $\begin{array}{l}\text { Total Value of Major Forest } \\
\text { Produce }\end{array}$ & & 4512.35 & 9617.74 & 5044.38 & $1.81^{\mathrm{NS}}$ & 28.36 \\
\hline & Total Outturn of Forest Produce & & 5540.61 & 11007.60 & 11138.46 & 7.42 & 13.00 \\
\hline
\end{tabular}

Note: As in Table 1 
Table 4:Compositional Changes in Forest Revenue and Expenditure in Maharashtra: 1980-94

(in per cent)

\begin{tabular}{|c|c|c|c|c|c|c|}
\hline \multirow{2}{*}{\multicolumn{2}{|c|}{ Source/Activity }} & \multicolumn{3}{|c|}{ Triennium Ending } & \multicolumn{2}{|c|}{ 1980-1994 } \\
\hline & & $1982 / 83$ & $1988 / 89$ & $1993 / 94$ & CGR $(\%)$ & CII (\%) \\
\hline \multicolumn{7}{|c|}{ Revenue Source } \\
\hline I & Timber & 51.91 & 63.80 & 34.62 & $-1.39^{\mathrm{NS}}$ & 22.25 \\
\hline ii & Firewood & 7.15 & 6.60 & 2.12 & -8.50 & 50.91 \\
\hline iii & Bamboo & 3.56 & 2.88 & 18.75 & $5.22^{\mathrm{NS}}$ & 90.71 \\
\hline iv & Grass and Grazing & 0.81 & 0.77 & 0.67 & $-2.95^{\mathrm{NS}}$ & 38.71 \\
\hline $\mathrm{V}$ & Bidi Leaves & 13.67 & 11.42 & 39.23 & 9.72 & 48.29 \\
\hline vi & Gum & 0.31 & 0.18 & 0.11 & -9.45 & 33.98 \\
\hline vii & Hirda & 0.09 & 0.02 & 0.05 & $-8.02^{\mathrm{NS}}$ & 89.80 \\
\hline viii & Other M. F. P. & 0.33 & 0.32 & 0.21 & $-3.36^{\mathrm{NS}}$ & 49.07 \\
\hline ix & Other Receipt & 3.68 & 3.86 & 4.16 & $1.59^{\mathrm{NS}}$ & 47.32 \\
\hline $\mathrm{x}$ & Total & 81.48 & 89.85 & 99.92 & 1.95 & 11.51 \\
\hline $\mathrm{xi}$ & Receipts from FDCM & 18.58 & 10.24 & 0.11 & -24.26 & 287.46 \\
\hline xii & Grand Total & 100.06 & 100.09 & 100.03 & - & - \\
\hline xiii & Refunds & 0.06 & 0.09 & 0.03 & $-4.63^{N S}$ & 62.61 \\
\hline & Net Revenue & 100.00 & 100.00 & 100.00 & - & - \\
\hline \multicolumn{7}{|c|}{ Expenditure Activity } \\
\hline$\overline{\mathrm{i}}$ & $\begin{array}{l}\text { General Direction and } \\
\text { Administration }\end{array}$ & 2.34 & 2.51 & 2.55 & 2.73 & 16.71 \\
\hline ii & Research/Education and Training & 1.98 & 2.37 & 1.70 & $-2.63^{\mathrm{NS}}$ & 27.40 \\
\hline iii & Administration and Protection & 21.59 & 24.02 & 26.68 & $-0.09^{\mathrm{NS}}$ & 15.49 \\
\hline iv & $\begin{array}{l}\text { Natural and Artificial Regeneration } \\
\text { and Plantation }\end{array}$ & 6.20 & 7.85 & 14.63 & 8.84 & 34.94 \\
\hline $\mathrm{V}$ & $\begin{array}{l}\text { Survey Settlement and } \\
\text { Demarcation, Forest Resources } \\
\text { Survey, etc. }\end{array}$ & 1.27 & 1.05 & 1.30 & $-0.08^{\mathrm{NS}}$ & 18.01 \\
\hline vi & $\begin{array}{l}\text { Afforestation and Soil } \\
\text { Conservation(including RVP) }\end{array}$ & 2.33 & 6.46 & 11.40 & 16.59 & 64.76 \\
\hline vii & Harvesting of Forest Produce & 23.86 & 22.46 & 13.72 & -3.96 & 29.72 \\
\hline viii & Processing Units & 3.14 & 1.48 & 0.37 & -14.90 & 23.37 \\
\hline ix & Roads and Bridges & 1.69 & 1.11 & 1.18 & $-4.49^{\mathrm{NS}}$ & 28.80 \\
\hline $\mathrm{x}$ & Buidlings & 0.80 & 1.58 & 1.57 & $4.49^{\mathrm{NS}}$ & 84.24 \\
\hline $\mathrm{xi}$ & $\begin{array}{l}\text { Wildlife Management, Nature } \\
\text { Conservation,etc. }\end{array}$ & 2.14 & 3.48 & 4.61 & $4.26^{\mathrm{NS}}$ & 52.93 \\
\hline xii & $\begin{array}{l}\text { Forest Labour Welfare and Similar } \\
\text { Activities }\end{array}$ & 0.72 & 1.19 & 0.50 & $8.48^{\mathrm{NS}}$ & 221.28 \\
\hline xiii & FDCM Ltd. Loans and Payments & 21.33 & 12.13 & 10.60 & -8.43 & 15.97 \\
\hline xiv & $\begin{array}{l}\text { DPAP,Western Ghat Development, } \\
\text { Grants to ZP }\end{array}$ & 10.54 & 11.32 & 9.06 & $0.93^{\mathrm{NS}}$ & 33.96 \\
\hline $\mathrm{XV}$ & $\begin{array}{l}\text { Scheme Implemented through } \\
\text { Receipts of F.D. Tax }\end{array}$ & 0.07 & 0.99 & 0.13 & $37.84^{\mathrm{NS}}$ & 768.13 \\
\hline & Total Expenditure & 100.00 & 100.00 & 100.00 & - & - \\
\hline
\end{tabular}

Note: As in Table 1 
Table 5: Human Labour Employment During Various Forest Related Operations In Maharashtra (employment in '000' mandays ; Wages paid in lakh rupees)

\begin{tabular}{|c|c|c|c|c|c|c|}
\hline \multirow{3}{*}{ Activity } & \multirow{2}{*}{\multicolumn{3}{|c|}{$\begin{array}{c}\text { Labour Employment } \\
\text { Triennium Ending }\end{array}$}} & \multirow{2}{*}{\multicolumn{3}{|c|}{$\begin{array}{c}\text { Wages Paid } \\
\text { Triennium Ending }\end{array}$}} \\
\hline & & & & & & \\
\hline & $1982 / 83$ & $1988 / 89$ & $1993 / 94$ & $1982 / 83$ & $1988 / 89$ & $1993 / 94$ \\
\hline $\begin{array}{l}\text { 1. Improvement, } \\
\text { organization } \\
\text { And extension }\end{array}$ & $\begin{array}{r}4291 \\
(15.96)\end{array}$ & $\begin{array}{r}8669 \\
(25.26)\end{array}$ & $\begin{array}{r}14861 \\
(43.93)\end{array}$ & $\begin{array}{r}300 \\
(16.08)\end{array}$ & $\begin{array}{r}1040 \\
(25.25)\end{array}$ & $\begin{array}{r}4013 \\
(53.50)\end{array}$ \\
\hline $\begin{array}{l}\text { 2. Exploitation of Forest } \\
\text { produce }\end{array}$ & $\begin{array}{r}12150 \\
(45.21)\end{array}$ & $\begin{array}{r}9756 \\
(28.43)\end{array}$ & $\begin{array}{r}1966 \\
(5.81)\end{array}$ & $\begin{array}{r}839 \\
(44.96)\end{array}$ & $\begin{array}{r}1143 \\
(27.75)\end{array}$ & $\begin{array}{r}531 \\
(7.08)\end{array}$ \\
\hline 3. Communication & $\begin{array}{r}929 \\
(3.46)\end{array}$ & $\begin{array}{r}455 \\
(1.33)\end{array}$ & $\begin{array}{r}23 \\
(0.07)\end{array}$ & $\begin{array}{r}67 \\
(3.59)\end{array}$ & $\begin{array}{r}53 \\
(1.28)\end{array}$ & $\begin{array}{r}6 \\
(0.08)\end{array}$ \\
\hline 4. Buildings & $\begin{array}{r}191 \\
(0.71) \\
\end{array}$ & $\begin{array}{r}367 \\
(1.07)\end{array}$ & $\begin{array}{r}120 \\
(0.35) \\
\end{array}$ & $\begin{array}{r}11 \\
(0.59)\end{array}$ & $\begin{array}{r}44 \\
(1.07)\end{array}$ & $\begin{array}{r}32 \\
(0.43) \\
\end{array}$ \\
\hline $\begin{array}{l}\text { 5. Draught Prone Area } \\
\text { Programme, Western Ghat } \\
\text { Development and IRDP }\end{array}$ & $\begin{array}{r}2367 \\
(8.81)\end{array}$ & $\begin{array}{r}4160 \\
(12.12)\end{array}$ & $\begin{array}{r}2013 \\
(5.96)\end{array}$ & $\begin{array}{r}165 \\
(8.84)\end{array}$ & $\begin{array}{r}530 \\
(12.87)\end{array}$ & $\begin{array}{r}543 \\
(7.24)\end{array}$ \\
\hline $\begin{array}{l}\text { 6. Employment Guarantee } \\
\text { Scheme }\end{array}$ & $\begin{array}{r}6949 \\
(25.85) \\
\end{array}$ & $\begin{array}{r}10908 \\
(31.79) \\
\end{array}$ & $\begin{array}{r}14845 \\
(43.88) \\
\end{array}$ & $\begin{array}{r}484 \\
(25.94) \\
\end{array}$ & $\begin{array}{r}1309 \\
(31.78) \\
\end{array}$ & $\begin{array}{r}2375 \\
(31.67) \\
\end{array}$ \\
\hline Total & 26877 & 34315 & 33828 & 1866 & 4119 & 7500 \\
\hline
\end{tabular}

Note: Figures in parentheses are percentages to the total labour employment / wages paid to labour

Appendix 1: Land Use Pattern in Maharashtra

(Area in '000' hectares)

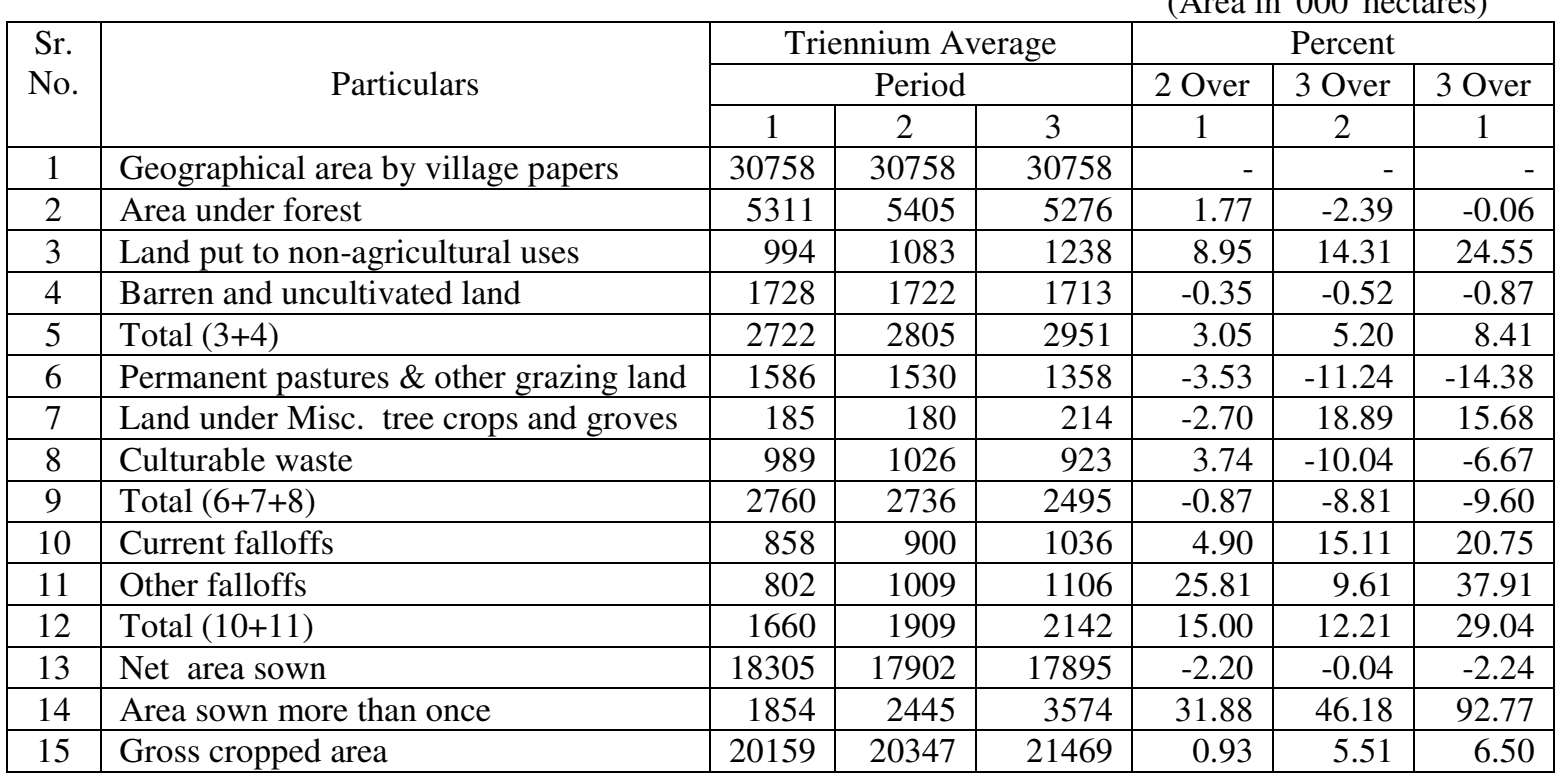

Note: Period $1=1980 / 81$ - 1982/83 ; Period 2 = 1987/88 - 1989/90 ; Period 3 = 1994/95 - 1996/97

Source: Handbook of Basic Statistics of Maharashtra State (various issues), Directorate of

Economics and Statistics, Government of Maharashtra, Mumbai. 
Appendix 2: Amount of Outstanding Forest Revenue Due to Various Resources

(Amount in lakh Rs.)

\begin{tabular}{|c|c|c|c|c|c|c|c|}
\hline \multirow{3}{*}{\multicolumn{2}{|c|}{ Reasons }} & \multicolumn{3}{|c|}{ Triennium Average } & \multirow{2}{*}{\multicolumn{3}{|c|}{$\begin{array}{l}\text { Share } \\
\text { Period }\end{array}$}} \\
\hline & & \multicolumn{3}{|c|}{ Period } & \multicolumn{2}{|r|}{ Period } & \\
\hline & & 1 & 2 & 3 & 1 & 2 & 3 \\
\hline $\mathrm{i}$ & $\begin{array}{l}\text { Non-receipt of dues from } \\
\text { FLCS }\end{array}$ & 103.76 & 277.89 & 261.58 & 13.56 & 16.51 & 13.19 \\
\hline ii & $\begin{array}{l}\text { Revenue due from forest } \\
\text { contractors }\end{array}$ & 460.08 & 916.47 & 1310.19 & 60.11 & 54.45 & 66.04 \\
\hline iii & $\begin{array}{l}\text { Non-receipt of Challans } \\
\text { from treasury }\end{array}$ & 87.95 & 285.21 & 56.12 & 11.49 & 16.95 & 2.83 \\
\hline iv & $\begin{array}{l}\text { Cases referred to revenue } \\
\text { authorities }\end{array}$ & 50.71 & 88.74 & 144.72 & 6.63 & 5.27 & 7.29 \\
\hline $\mathrm{V}$ & $\begin{array}{l}\text { Cases under court } \\
\text { proceedings }\end{array}$ & 7.71 & 22.51 & 27.16 & 1.01 & 1.34 & 1.37 \\
\hline vi & Miscellaneous & 55.15 & 92.31 & 184.04 & 7.20 & 5.48 & 9.28 \\
\hline & Total & 765.36 & 1683.13 & 1983.81 & 100.00 & 100.00 & 100.00 \\
\hline
\end{tabular}

Note: Period $1=1980 / 81-1982 / 83 ;$ Period $2=1986 / 87-1988 / 89 ;$ Period $3=1991 / 92-1993 / 94$

Appendix 3: Afforestation Under Various Activities in Maharashtra

(Area in Hectare)

\begin{tabular}{|c|c|c|c|c|c|c|c|}
\hline \multirow{3}{*}{\multicolumn{2}{|c|}{ Scheme/Programme }} & \multirow{2}{*}{\multicolumn{3}{|c|}{$\frac{\text { Triennium Average }}{\text { Period }}$}} & \multirow{2}{*}{\multicolumn{3}{|c|}{$\begin{array}{c}\text { Percent Share } \\
\text { Period } \\
\end{array}$}} \\
\hline & & & & & & & \\
\hline & & 1 & 2 & 3 & 1 & 2 & 3 \\
\hline $\mathrm{i}$ & Plan Scheme & 3652.00 & 9083.67 & 16209.00 & 14.35 & 15.60 & 24.02 \\
\hline ii & $\begin{array}{l}\text { Draught Prone Area } \\
\text { Programme (DPAP) }\end{array}$ & 5146.00 & 3525.00 & 1800.00 & 20.23 & 6.05 & 2.67 \\
\hline iii & $\begin{array}{l}\text { Integrated Rural } \\
\text { Development Programme } \\
\text { (IRDP) }\end{array}$ & 151.67 & 128.33 & - & 0.60 & 0.22 & - \\
\hline iv & $\begin{array}{l}\text { Western Ghat } \\
\text { Development Programme }\end{array}$ & 1589.67 & 3578.67 & 6138.00 & 6.25 & 6.15 & 9.10 \\
\hline $\mathrm{v}$ & $\begin{array}{l}\text { Employment Guarantee } \\
\text { Scheme }\end{array}$ & 14903.00 & 41909.67 & 43326.00 & 58.57 & 71.98 & 64.21 \\
\hline & Total & 25442.34 & 58225.34 & 67473.00 & 100.00 & 100.00 & 100.00 \\
\hline
\end{tabular}

Note: Period 1 = 1980/81 - 1982/83; Period 2 = 1986/87-1988/89; Period 3 = 1991/92 - 1993/94 
Appendix 4: Working of Forest Labour Co-operative Societies (FLCS) in Maharashtra

\begin{tabular}{|l|l|r|r|r|r|r|r|}
\hline \multirow{2}{*}{\multicolumn{2}{|c|}{ Particulars }} & \multicolumn{3}{c|}{ Triennium Average } & \multicolumn{3}{c|}{ Percent Change } \\
\cline { 3 - 8 } \multicolumn{2}{|c|}{} & \multicolumn{3}{|c|}{ Period } & 2 over & \multicolumn{1}{c|}{3 over } & 3 over \\
\cline { 3 - 8 } & 1 & 2 & 3 & 1 & 2 & 1 \\
\hline i & No. of Societies & 151 & 327 & 271 & 116.56 & -17.13 & 79.47 \\
\hline ii & No. of Functional Societies & 151 & 303 & 204 & 100.66 & -32.67 & 35.10 \\
\hline iii & No. of Coupes Worked & 324 & 323 & 34 & -0.31 & -89.47 & -89.51 \\
\hline iv & $\begin{array}{l}\text { Area Harvested by FLCS } \\
\text { in Ha) }\end{array}$ & 32756 & 19477 & 3087 & -40.54 & -84.15 & -90.58 \\
\hline v & $\begin{array}{l}\text { Total Realization (Rs. in } \\
\text { lakhs) }\end{array}$ & 1025 & 1751 & 371 & 70.83 & -78.81 & -69.80 \\
\hline
\end{tabular}

Note: Period 1 = 1980/81 - 1982/83; Period 2 = 1986/87-1988/89; Period 3 = 1991/92 - 1993/94 